\title{
Leaders - Deceptions and Convenient Lies
}

\author{
THAMER ALSUBAIE \\ Media and Communication, Imam University, PO box 21331, Jeddah 104458, Saudi Arabia
}

\begin{abstract}
Generally speaking, when we deal with the issue of leadership in the context of international relations and diplomacy, the power of individual character of a leader is an important element of the analysis. Public is usually attracted by leaders of outstanding personality, able to influence the politics at home and in prevailing circumstances in international relations.According to the authors of textbook on leadership proposed for this course, people are attracted by those who lead, because whatever comes from the ways they do right or wrong can influence lives of millions on a large scale. But, it is not the matter of looking on position of a leader, sometimes acting behind bombastic titles like "beloved leader" or "dear comrade", etc. Rather, it is the matter of looking on leaders in action in domestic and foreign policy, because decisions they make can sometimes influence the course of international relations even after a period when they act as leaders.As one of primary concerns of public is to look on ways leaders use their power, it leads experts in politics to consider leadership as a rather complex and multidimensional exercise. Some people believe that interaction between leaders and followers is happening in mysterious ways. But there is nothing mysterious in the plain fact that both leaders and followers influence each other in due process, in prevailing conditions of their time and in locations where they act. Undoubtedly, the actual conditions in overall international relations do affect largely the attitude of leaders, and in circumstances of the great change they and states they lead can become central actors in re-creating the international system as well. According to the authors of "Essentials of International Relations", available through the Internet, "leaders of hegemonic states", for example, "can take decisions that shape international political economy". In this context they observe, among other things, the following: "In this special context of the 2003 Gulf war and invasion of Iraq, leading to the destitution of Saddam Hussein, can we say that because of the arrogant attitude of former Iraqi president and the overconfidence of his advisers that the USA launched its invasion to make an end to a long era of dictatorship and tyranny."When another author John Mearsheimer wrote about lying in international politics, suggested as additional reading for our course, he observed how sometimes leaders engage directly, or allow other leading officials of the state, to produce deceptions and so-called convenient lies in politics. His impressive research included also the references to 2004 U.S. presidential campaign when John Kerry, acting at time as the senator, stated how President George W. Bush, in the case of alleged decision of Saddam Hussein to possess material for nuclear arms, "failed to tell the truth" about Iraq and "misled the American people".In this context, this author argued that there are sometimes "good strategic reasons for leaders to lie to other countries as well as to their own people; international lying, in other words, is not necessarily misconduct; in fact, it is often thought to be clever, necessary and maybe even virtuous in some circumstances". Going further through his writings, I gained the motivation to work on it within my end term paper, to reflect upon some aspects of this interesting issue, trying to understand better how it reflects upon views on leadership process that are in today's world of power of media under constant scrutiny.
\end{abstract}

Keywords: Leaders, Deceptions, Convenient Lies

DOI: $10.7176 / \mathrm{NMMC} / 78-05$

\section{Heading 1}

\section{SOME CHARACTERISTICS OF LEADERSHIP PROCESS}

It appears to me that whenever engaged in analysis of leadership as a complex process, it is necessary to examine both personal characteristics and way of thinking of individuals who lead nations and engage into a broader inter-action between nations and states. For, they sometimes take decisive actions that shape their foreign policy choices and hence the international relations at large.

The political psychologist Margaret Hermann, for example, found a number of personality characteristics that affect foreign policy behaviors. As political leaders do not generally take personality tests, she used different research strategy and systematically collected interviews and press conferences of 80 heads of states in 38 countries, during 1960s. The authors of "Essentials of International Relations" provided in some detail her findings presented in two charts, while using nowadays often used terms like "key personality characteristics", "foreign policy behavior" and/or "leader's orientation". The first chart address the issue of personality characteristics of leaders, in which Herman provides her views on what may affect leaders in due leadership process:

- A. High sense for Nationalism, which can be defined as strong emotional ties to nation or to political party, with strong emphasis on national honor and national pride.

- B. Perception of Control, which can be defined as a strong belief in ability to control all the events and 
situations.

- C. Urgent need for power, pushing this category of greedy leaders to establish, maintain and project power and influence over the other.

- D. Need for adherence, through affiliation by establishing and maintaining strong relationships with others.

- E. Ideological complexity, and an absence of ability to discuss openly and democratically with other people ideas in a logical and non-offensive manner.

- F. Complete distrust of others, accompanied with a high feeling and sense of doubt and suspicion of the others.

In the second chart she described different "foreign policy orientations", in other words the foreign policy choices of leaders, characterizing them as in high or low dimension, depending of what was predominant element as provided in her first chart. In the process she came to conclusion that leadership is a rather complex process, whenever societies function outside a framework of democracy. In this context she referred to extreme case of the North Korean regime under the rule of Kim Il Sung and after him of his late son Kim Jong-Il, who used army and their communist party to impose their totalitarian views, tyranny and oppression.

But, the positive side in personal character of a leader and choices made in foreign policy, she recognized in leadership process through which the former Soviet leader Mikhail Gorbachev had gone from 1986, to the end of Soviet Union in 1991. This man tried his best to introduce massive changes in Soviet communist concept of domestic and foreign policy, and influenced largely the overall international relations, leading to the end of Cold war era. Both his and the example of North Korean regime provide a picture of leaders with rather different individual characteristics and different outcomes of their politics, domestically and internationally.

\section{SEVERAL DIMENSIONS OF LEADERSHIP}

The authors of textbook about enhancing the lessons of leadership experience also find that the leadership process has multifaceted dimensions. As those dimensions can involve both rational and emotional sides of human experience, "the leadership can be defined as both a science and art". In this context they provide the following opinion: "Because people differ in their thoughts and feelings, hopes and dreams, needs and fears, goals and ambitions, and strengths and weaknesses, leadership situations can be complex. People are both rational and emotional, so leaders can use rational techniques and emotional appeals to influence followers, but they must also weigh rational and emotional consequences of their actions".

Besides politics, bad or good leadership is today recognized in international business and trade as well. In this framework leadership obtains more evident managerial dimension that nowadays provide new advantages for managers while performing as leaders in their field of professional expertise. There are certain important differences when one compare the challenges of statecraft in times of tense international relations and postconflict situations, but many authors today see leaders as managers of great companies, while some leaders really behave like professional managers in charge of fixing problems quickly and less costly.

As the authors of textbook about lessons of leadership suggest, leaders today must be more innovative in developing new strategies, while managers as leading administrators must concentrate on executing and maintaining the value of such new strategies. In addition, leaders are endowed with a long-term vision and should inspire individuals, whereas managers must be good controllers, with a short-term vision in accomplishing the goals. Equally important to them, the leaders should produce originality and ask pertinent core questions, whereas managers must often imitate original versions and ask seemingly less important questions in terms of development of society and state and its inter-state relations worldwide. At the end they summarized well differences in dimensions of leadership: "Leaders are thought to the right things, whereas managers are thought to do things right".

What cannot be forgotten also is the fact that effective leaders must follow decisions and choices of their followers, simply because they share ideas about the ways their society should function and what it should do in international relations. It is the mark of this era that the role of women in politics is greatly enhanced as well. The performance of Margaret Thatcher in late 1980s, or the continuous success of Angela Merkel in Germany today, provide excellent examples of the creative contribution of women facing challenges of leadership. Or, take the example of Aung San Suu Kyi of Myanmar, known before as Burma, who is also perceived as the prominent and charismatic voice for freedom and democratic change, for what she obtained the Nobel Prize for peace. Like the late South-African leader Nelson Mandela, she has become an international symbol of heroic and peaceful resistance, facing the oppression of militaristic regimes of one or another kind.

\section{SOME FORMS OF DECEPTIONS AND CONVENIENT LIES}

As previously noted, the notion of leadership has multifaceted dimensions as it involves both rational and emotional sides of experience of individuals who act leaders. For this specific reason, in certain cases the followers face ugly realities in which their leaders use different instruments and tools to provide strategic coversup of the real nature of their personality and of their politics, producing stories that distort truth and create false 
impressions.

For example, during the U.S. intervention in Iraq in 2003, the Iraqi Minister of Information, acting under Saddam Hussein's regime, himself member of the inner circle of the ruling Baath Party, several times preached over state controlled TV how the military leadership of his Commander in Chief, Saddam Hussein himself, will annihilate the U.S. forces in different parts of Iraq and how the Iraqi people fight against them everywhere with great success.

But, after the U.S. forces entered the Iraqi capital Bagdad, they were welcomed as liberators by thousands on streets, in obvious denial of previous stories of officials in Saddam Hussein's regime, clearly manifesting the damaging results of manipulative and misleading nature of their leader. The impact of the fall of this regime in other Arab capitals was so big that since a large number of his one time sympathizers would not trust another charismatic leaders operating like Saddam Hussein did.

During my research the defeat of the Arab armies in 1967 Israeli-Arab war presented to me another example of the use of deceptions and convenient lies. It is very hard to deny that the nationalist Arab Egyptian leader Gamal Abdel Nasser did enjoy the great esteem of the Arab peoples in all corners of the Arab world, particularly after the 1956 Canal Suez crisis and the war which alliance between France, Great Britain and Israel imposed on Egypt. His resistance against three powers was his symbolic victory, but by 1967 he faced another direct war with Israel and failed in his calculations. After the defeat in 1967 War, for the large majority among the Arab population it was very hard to accept the reality of his defeat and of Egypt under his leadership alone. To me, it relates directly to what the authors of above-mentioned textbook on leaders had to say about leader's need to focus on actual situation:

"Perhaps the most important situational factor associated with charismatic leadership is the presence or absence of a crisis. Followers who are content with status quo are relatively unlikely to perceive a need for a charismatic leader, or be willing to devote great efforts to fundamentally change the organization of society. On the other hand, a crisis often creates "charisma hungry" followers, looking for a leader to alleviate or resolve their crisis".

Going back to writings of John Mearsheimer, it appears that contrary to prevailing public opinion leaders very rarely turn towards deceptions and convenient lies in their relations with leaders of other countries. Instead, they seem more inclined to use them when they talk about foreign policy issues to their own people, particularly when they are engaged in projecting their ambitious foreign policy and need to cover-up their use of force, even in situations when the problem does not necessarily pose clear danger to vital interests of the country they lead.

In such circumstances, some leaders believe they have good strategic reasons to say things or purposely imply things that they know are not true. Their public usually do not punish them for their deceptions unless they produce bad results, and often both leaders and their public believe that using deceptions and cheating is an integral part of international relations. This is not to say that many leaders would not prefer to see the international arena governed by a well-defined set of moral principles. But, as this is not feasible because there is no common sovereign to enforce such principles, it is easier to produce deceptions and politically convenient lies that often take different forms, including so-called concealment and spinning of facts, making false statements and telling stories with a false bottom. Such distinctive forms of deception are particularly pervasive and the local and international politics provide fertile breeding ground for spinning and concealing.

For example, a head of a state today can tell to citizens a story about the state of their economy that provides picture about positive trends, while downplaying or even ignoring obvious negative results and trends, without a significant political harm. This is particularly true if a foreign policy issue is at stake; leaders and other state officials are almost never punished for distorting truth in their relations with the outside world.

It draws the attention towards another method often used by teams working on behalf of interests of leaders: creating strategic cover-ups. As Professor Mearsheimer suggests, they take two forms. The first relates to the situations in which leaders take a decision "to cover-up the policy that has gone badly wrong". Sometimes it is done to protect interests of the country in manner they see those interests, not necessarily to protect individuals for the policy failure though it often happens as an unintended consequence.

But, they can also decide to implement strategic cover-ups to hide a controversial but for them smart strategy, because they fear that it will meet serious public resistance. In both cases they believe that there are sound strategic reasons for the cover-ups in trying to deviate or conceal the real nature of the issue for what they judge to be the good of the country they govern. They can also decide to do it determined to conceal there own of their military and political allies incompetence, which caused the problem they do not want their political rivals and enemies to see and eventually exploit. In such cases the strategic cover-ups are not any more only domestic or inter-state lies, because today they are widely disseminated through media to own people as well as to the outside world.

\section{USES AND MISUSES OF MYTHS}


Into this picture comes the story of the uses and misuses of nationalist myths and of religious views. In fact, throughout history the leaders used nationalist ideology to build strong ties with their followers. This can be clearly seen in most of the contemporary regional conflicts as well, whenever there is the struggle between opposing national and cultural interests, with their spill over effects on a larger scale. In this sense it is important to study extreme nationalist or chauvinist myths, because they often produce very damaging results. They are created in a wider social process in which the own sacred myths about the past are portrayed in a favourable way, while the myths among the rivals are portrayed in a negative way.

Some political theorists argue that nationalist myths "come in three principal varieties: self-glorifying, selfwhitewashing and other maligning". The common people are usually hungry for such myths and like to hear stories about the past in which they are portrayed as good guys while the opposing nations are portrayed as bad guys.

As John Mearsheimer suggests, "the nationalist myths are driven from below as well as from above". In the process most people are usually so much taken by their nation's myths that they do not recognize the attempt of their leaders to distort the truth and with it the historical record too. But, in such circumstances the risks of nationalist mythmaking can become great, leading people to collective self-delusion, while even the most sophisticated elite may fall victim and end up believing in own myths, projecting them through leaders and their official policy.

To me the wars in the Balkans during 1990s represent the pertinent example of the use and misuse of national myths by leaders engaged in re-composition of their previously common Yugoslav territory. As the result, the five years long violent conflict in Bosnia between the Serbs and the Croats over the interests of majority of Bosnians was motivated by nationalist claims of each side, while the later intervention of external countries aimed to arrest the carnage and prevent the rising influence of opposing religious claims.

In another example, the intervention of Soviet armed forces in Afghanistan in 1980s that shaken to the ground the national and religious balance in this country, soon obtained the form of indirect conflict between the two leading powers of Cold war era. But, it also became the first case of massive participation of local and foreign Mujahidin, as the religious martyrs, encouraged in struggle against the Soviet occupation, supported by the U.S. Special Forces.

To me the most persistent use and misuse of myths is still in evidence in the Middle East, primarily in the context of long Israeli-Palestinian conflict. On one side stand national and religious Jewish myths about the right of return of sons of Israel to East Jerusalem and to their temple destroyed by Romans in distant past. On other side stand Muslims, for whom East Jerusalem remains the part of Islamic credo, with the historic importance of the three holy shrines in Islam.

\section{CONCLUSIONS}

The study of challenges of leadership provides the opportunity to examine the unavoidable and often central role of leaders in shaping domestic foreign policy priorities and in projecting them in international relations. It also suggests that some leaders, with their own personality characteristics, in crucial moments in history, can as statesmen make the direct impact not only on foreign policy orientation of their states, but on state of prevailing international system of their era, as well.

In this context, it appears to me that sense of orders and disorders in prevailing international system are grounded in internal social relations of each society and performance of their leaders. It means to me that any significant structural change in world order is linked to fundamental changes in relations between state leaders as well, particularly when they are engaged in adapting the national structures to great changes on international scene. In this context leadership represents an essential part of new national structures and only democratic rulers can ensure stable social relations at home and indirectly positive international relations.

In this sense, both domestic politics and international relations are interrelated: a country's international position exerts an important impact on its internal politics and economy and vice-versa, and its domestic situation shapes its behavior in foreign relations. While looking on historic records I also recognize that democratic leaders are less likely prone to choose the war as the sole option in their relations with other states. Except in extreme cases, when domestic factors of adversaries are driven by non-democratic elements, pushing even their own charismatic leaders to fall into despotism and dictatorship, with extremely negative implications for the international relations, as well.

For me, the problems in international relations grow faster whenever certain leaders try to use deceptions and convenient lies to distort the historical record and the prevailing realities in times when they are in charge of politics and economy in their society. As John Mearsheimer in this context left to our better understanding the risks of nationalist mythmaking, it appears that with such leaders "even sophisticated national elites sometimes end up believing their own lies in which case they are no longer lies". But, as he also warns, "foreign policy behavior drives the creation of nationalist myths, not the other way around". In this way the chauvinist myths are deployed to justify the actions and actual belligerent intentions. And then, in newly created circumstances, the 
militant nationalism can become a potent cause of war. It appears that leaders of all kinds sometimes obviously think that deceptions and convenient lies in politics could be useful tools in their performance, to be deployed in circumstances that fit to their agenda.

\section{References}

1. Richard L. Hughes, Robert C. Ginnett, Gordon J. Curphy, Leadership - Enhancing the Lessons of Experience, Seventh Edition, McGraw-Hill Irwin, New York, 2012

2. John J. Mearsheimer, Why Leaders Lie - The Truth About Lying in International Politics, Oxford University Press, 2011

3. Karen A. Mingst, Ivan M. Arreguin-Toft, Essentials of International Relations, Fifth Edition, Norton \& Company, as available at the Internet, 2011

4. Helen N. Milner, Interests, Institutions and International Relations, Princeton University Press, USA, 1997

5. Nebo Dimitrijevic, Briefing Notes for the Course on Challenges of Leadership Today, Fall 2014, including relevant articles available in Foreign Affairs and Foreign Policy journals 